\title{
Influence of surface treatment conditions for organic crystalline scintillators on their scintillation characteristics
}

\author{
V.O.Tarasov ${ }^{1}$, L.A.Andryushchenko ${ }^{2}$, O.V.Dudnik ${ }^{3,4}$, E.A.Rybka $^{2}$ \\ 1Institute for Scintillation Materials, STC "Institute for Single Crystals", \\ National Academy of Sciences of Ukraine, 60 Nauky Ave., 61072 Kharkiv, \\ Ukraine \\ ${ }^{2}$ National University of Civil Protection of Ukraine, 94 Chernyshevska \\ Str., 61023 Kharkiv, Ukraine \\ ${ }^{3}$ Institute of Radio Astronomy, National Academy of Sciences of Ukraine, \\ 4 Mystetstv Str., 61002 Kharkiv, Ukraine \\ ${ }^{4}$ V.Karazin Kharkiv National University, 4 Svobody Sq., 61022 Kharkiv, \\ Ukraine
}

\section{Received November 22, 2017}

The scintillation and optical characteristics of alpha and beta radiation detectors based on organic crystalline scintillators are investigated after the treatment of their surfaces with different compositions. The polishing composition has been matched, which ensures an improvement in the quality of the polished surface and an improvement in the stated characteristics of alpha and beta radiation detectors based on stilbene and activated $p$-terphenyl single crystals by increasing the light collection coefficient. The parameters of these detectors are retained after exposure to a temperature of $+60^{\circ} \mathrm{C}$ for $12 \mathrm{~h}$. It is also shown that the use of a matched polishing compound makes it possible to obtain a detector of high spectrometric quality based on an activated $p$-terphenyl single crystal $6 \times 6 \times 6 \mathrm{~mm}^{3}$ in coupling with a SiPM. The energy resolutions for this detector are 5.7, 7.9 and $11.9 \%$ when electrons of internal conversion with energies of 1048, 976 and $554 \mathrm{keV}$ are being registered.

Keywords: alpha and beta radiation detectors, organic crystalline scintillators, stilbene, $p$-terphenyl.

Исследованы сцинтилляционные и оптические характеристики детекторов альфа- и бета-излучения на основе органических кристаллических сцинтилляторов после обработки их поверхностей различными составами. Подобран полировальный состав, обеспечивающий повышение качества полированной поверхности и улучшение указанных характеристик детекторов альфа- и бета излучения на основе монокристаллов стильбена и активированного $n$-терфенила за счет повышения коэффициента сбора света сцинтилляций. Параметры этих детекторов сохраняются после воздействия температуры $+60^{\circ} \mathrm{C}$ в течение 12 ч. Использование подобранного полировального состава позволяет получить детектор высокого спектрометрического качества на основе монокристалла активированного $n$-терфенила размерами $6 \times 6 \times 6$ мм $^{3}$ в сочетании с кремниевым ФЭУ. Для указанного детектора энергетическое разрешение при регистрации электронов внутренней конверсии с энергиями 1048, 976 и 554 кэВ составляет 5.7, 7.9 и 11.9 \%, соответственно. 
Вплив умов обробки поверхні органічних кристалічних сцинтиляторів на їні сцинтиляційні характеристики. В.О.Тарасов, Л.А.Андрющенко, О.В.Дудник, С.О.Рибка

Досліджено сцинтиляційні та оптичні характеристики детекторів альфа- і бетавипромінювання на основі органічних кристалічних сцинтиляторів після обробки їніх вхідних поверхонь різними сумішами. Підібрано полірувальний склад, що забезпечує підвищення якості полірованої поверхні і поліпшення вказаних характеристик детекторів альфа- і бета- випромінювання на основі монокристалів стильбена та активованого $n$-терфеніла за рахунок підвищення коефіцієнта світлозбору сцинтиляцій. Параметри цих детекторів залишаються незмінними після дії на них термічних навантажень при температурі $+60^{\circ} \mathrm{C}$ протягом 12 год. Використання підібраного полірувального складу дозволяє отримати детектор високої спектрометричної якості на основі збірки 3 монокристала активованого $n$-терфеніла розмірами $6 \times 6 \times 6 \mathrm{~mm}^{3}$ та кремнієвого ФЕП. Для вказаного детектора енергетична роздільна здатність при реєстрації електронів внутрішньої конверсії з енергіями 1048, 976 і 554 кеВ складає 5.7, 7.9 і $11.9 \%$, відповідно.

\section{Introduction}

Organic scintillators are characterized by high-speed performance and high transparency to their own fluorescence. Possessing a property of a small effective atomic number, they have an advantage over inorganic scintillators when registering short stopping ranged radiations ( $\alpha$ - and $\beta$-particles). The most widely used effective organic scintillators were stilbene and activated with 1,4-diphenylbutadiene-1,3 (DPB) $p$-terphenyl single crystals $[1,2]$.

The use of organic crystalline scintillators for manufacturing of modern scintillation apparatus, in particular for space research and extreme radiation monitoring, imposes high demands on them: high optical characteristics and high accuracy of shape; compactness; high scintillation characteristics for the registration of $\alpha$ - and $\beta$ particles; operational stability [3-5].

The scintillation characteristics of detectors and their stability during operation depending on the properties of used scintillators, the design of the detectors, the conditions of their manufacture, and used photodetectors [6]. In the production of scintillation detectors, vacuum photomultiplier tubes (PMTs) [6-9], photodiodes [10, 11] and recently new photoreceivers - silicon PMs (SiPMs) [3, 4, 12] are widely used as a detectors for UV emission.

The solution of design tasks, when developing detectors based on organic crystals using SiPM with maximal sensitivity the smallest weight, is described in [4]. The effect of the scintillators surfaces state on optical, scintillation characteristics and their stability while the influence of climatic, mechanical and radiation factors is considered in $[6,13]$.
The main problems in the treatment of organic crystals' surfaces are the anisotropy of their properties, great brashness, low thermal conductivity [14]. The brashness of crystals, in particular, stilbene, is associated with the properties of cleavage planes and is the reason for the low yield of end products during machining. Under the influence of thermal and mechanical factors, stilbene single crystals are easily being cracked, usually along the cleavage plane (001). Therefore, the treatment of organic crystals is carried out taking into account their crystallographic orientation without easily volatile organic solvents used.

The method of deep grinding-polishing with successive reduction in the grain size of the abrasive powder of electrocorundum up to-M3 in the water-soap emulsion is used for end treatment of organic crystalline scintillators' surfaces [6]. The disadvantage of this method is the duration of the treatment process. In addition, mechanical polishing of organic crystals' surfaces can lead to the formation of elastic stresses in the near-surface layer. The relaxation of the latter (owing to the low energy of the crystal lattice) is accompanied even at room temperature by the generation of secondary defects-dislocations, microcracks (and the formation of a polycrystalline layer). The outcrop of defects on the surface is accompanied by the formation of numerous caverns. This leads to a drop of optical properties and a deterioration in the scintillation characteristics of detectors.

A promising tool of crystal processing is the diamond micro-turning method $[13,15]$. The method eliminates abrasive grinding, reducing by such a way the laboriousness of the process in a whole. However, even after diamond micro-turning, additional final processing is being required, in particular, 
to remove the fine scratches (diamond background) grid and to reduce the surface roughness. A promising area for final processing of scintillators surfaces is the method of chemical-mechanical polishing using nanosized powders [13], which is widely used in micro- and nanotechnology. For example, polishing of semiconductor wafers in the electronics industry is carried out using commercial (Degussa and Wacker - Germany, Nalko - USA) dispersions containing nano-sized particles of silicon dioxide. So, Aerosil OX-50 (Degussa, Germany), with a weak aggregation of primary particles, in a liquid medium gives stable suspensions whose dispersed phase consists predominantly of individual primary particles $(d \sim \varnothing 40 \mathrm{~nm})[16]$.

The analysis carried out in [17] shows that polishing using suspensions containing nanoscale particles leads to the formation of scratches whose width, along with the roughness, correlates with the particle size. In some cases, the width exceeds the particle size. This indicates that the surface relief is formed under the influence of both primary particles and their aggregates. The ratio of the participation of these two factors differs for different materials and compositions of polishing compositions [17].

The process of chemical-mechanical polishing means repetitive cycles of removal from the crystal surface of a thin layer of a substance having a lower strength than an undamaged layer. Such a substance can be reaction products or an initial material that has experienced the diffusion effects of working fluid components [18]. The nature of the wetting liquid has a significant effect on the characteristics of the polished surface. Substantial difficulties arise when it is selected for such brittle materials as organic crystals. To increase the processing capacity, on the one hand, it is necessary that it has a great wedging effect. On the other hand, this leads to the emergence of a large number of microcracks, to decrease in the fineness and perfection of the treated surface.

The possibility of improving the surface quality of activated $p$-terphenyl crystals by chemical-mechanical polishing using a polishing powder of aluminum oxide with a particle size of $80-90 \mathrm{~nm}$ was demonstrated in [19]. As a polishing liquid, a mixture of ethanol and toluene was used. However, this method does not provide high accuracy in the shape of scintillator assembled with SiPM, which in possession of the very small photosensitive area. The use of a mixture of ethanol and toluene in the polishing compound as a wetting liquid results in partial dissolution of the scintillators and deviation of the linear dimensions from the given geometry. The purpose of this work is to continue and extend research aimed at improving the surface quality of organic crystalline scintillators, on maintaining high precision of shapes, on improving scintillation characteristics and increasing their stability during operation.

\section{Experimental}

As objects of research, scintillator samples based on stilbene single crystals and activated $p$-terphenyl single crystals with dimensions of $\varnothing 15 \times 2 \mathrm{~mm}, \varnothing 30 \times 2 \mathrm{~mm}$, $\varnothing 30 \times 5 \mathrm{~mm}$, and also a single crystal of activated $p$-terphenyl of $6 \times 6 \times 6 \mathrm{~mm}^{3}$ were selected. The scintillator samples were obtained by diamond microturning using a natural diamond cutter on a special machine-tool such as MK 6205 .

One of the main tasks of scintillator surfaces' processing is to increase the portion of light coming out toward the photodetector. In case of a flat scintillator, it is necessary to ensure a good reflection of the scintillation light from its input surface and to increase the probability of light coming out through output surface. The first one is being achieved by polishing the input surface, and the second one by making a rough surface of the scintillator.

A film polymer material containing an abrasive powder with a particle size of the main fraction of $10 \mu \mathrm{m}$ was used to create a diffusely reflecting output surface of scintillators. The film polymer base does not allow abrasive grains to crumble or be pressed into the surface of the crystal to be treated. It prevents significant disruption of the crystal structure of the surface layer, ensures a higher homogeneity of the scintillator output surface [16].

Two possibilities of polishing compounds have been used for final processing of the scintillator' input surface.

Composition No. 1, containing: 5 wt. parts of aluminum oxide with particle sizes of $80-90 \mathrm{~nm}, 86 \mathrm{wt}$. parts of ethanol and 9 wt. parts of toluene. This composition contains low viscosity wetting liquids that give a too thin layer between the last one and the polisher; it poorly retains the abrasive in the polisher. The last circumstance causes the appearance of individual scratches on the surface of the material being processed. The presence of toluene in 
Table 1. Optical and scintillation characteristics of single-crystalline organic scintillators when their input surfaces are treated with different polishing compounds

\begin{tabular}{|c|c|c|c|c|c|}
\hline \multirow[t]{2}{*}{ No. } & \multirow{2}{*}{$\begin{array}{l}\text { Scintillator material, } \\
\text { dimensions, } \mathrm{mm}\end{array}$} & \multirow{2}{*}{$\begin{array}{l}\text { Polishing } \\
\text { compound }\end{array}$} & \multirow{2}{*}{$\begin{array}{c}\text { Translucence, } \% \\
\text { on wavelength } \\
\lambda, \mathrm{nm}\end{array}$} & \multicolumn{2}{|c|}{ Scintillation characteristics* } \\
\hline & & & & $\begin{array}{l}\text { ADC channel } \\
\text { number }\end{array}$ & $\begin{array}{c}\text { Energy } \\
\text { resolution } R, \%\end{array}$ \\
\hline 1 & Stilbene single crystal $\varnothing 30 \times 2$ & 1 & $74.7 \lambda=390$ & 705 & 14.6 \\
\hline 2 & " & 2 & $77.8 \lambda=390$ & 820 & 13.4 \\
\hline 3 & Stilbene single crystal $\varnothing 15 \times 2$ & 1 & $75.4 \lambda=390$ & 720 & 14.9 \\
\hline 4 & 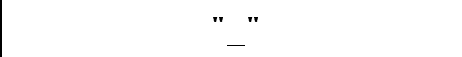 & 2 & $78.6 \lambda=390$ & 850 & 13.6 \\
\hline 5 & $\begin{array}{l}\text { Activated } p \text {-terphenyl single } \\
\text { crystal } \varnothing 30 \times 5\end{array}$ & 1 & $64.3 \lambda=420$ & 1015 & 11.9 \\
\hline 6 & $"=$ & 2 & $68.1 \lambda=420$ & 1130 & 10.4 \\
\hline
\end{tabular}

* - scintillation characteristics were obtained by excitation with $\alpha$-particles with an energy $E_{\alpha}=5.5 \mathrm{MeV}$ of radionuclide ${ }^{241} \mathrm{Am}$.

this composition can lead to a partial dissolution of the scintillator material and to the deviation of its size and shape from the preset values. The latter is especially important in case of scintillators with small dimensions assembled with SiPMs.

In this work, composition No. 1 is compared with a new composition No. 2 containing: 4 wt. parts of aluminum oxide with particle sizes of $80-90 \mathrm{~nm}, 3 \mathrm{wt}$. parts of silicon dioxide with particle sizes of 5$20 \mathrm{~nm}$ (Aerosil A300), 13 wt. parts of ethanol, 26 wt. parts of ethylene glycol and 54 wt. parts of distilled water. Silicon dioxide, water and ethylene glycol provide a gellike consistency of the composition with a high viscosity and do not dissolve organic crystals.

We have polished scintillators on a glass polisher covered with a soft cloth. The organosilicon compound "Sylgard-184" from "Dow Corning" company (USA) was used in order to couple optically the scintillators with the input windows of the photodetectors. This compound has been chosen because of its high optical, physicochemical and mechanical properties [17, 18].

We've used the Tetratex polymer as a reflector material when registering electrons. Measurements of the translucence of p-terphenyl crystals' samples were carried out on a SF-26 type spectrophotometer.

A study of the scintillation characteristics of detectors based on stilbene single crystal and activated $p$-terphenyl single crystals with dimensions of $\varnothing 15 \times 2 \mathrm{~mm}$, $\varnothing 30 \times 2 \mathrm{~mm}, \varnothing 30 \times 5 \mathrm{~mm}$ was performed in a pulsed mode. At these measurements, the PMT R-1307 photoreceiver of "Hamamatsu Photonics" production has been used. The radionuclide of ${ }^{241} \mathrm{Am}$ served as the source of $\alpha$-particles with an energy of $E_{\alpha}=$ $5.5 \mathrm{MeV}$. The time constant of the analog signal shaper was set at the level of $\tau=1 \mu$ s. Additionally, the radionuclide of ${ }^{137} \mathrm{Cs}$ served as the source of conversion electrons with an energy $E_{e}=624 \mathrm{keV}$. After measuring the scintillation characteristics detectors were exposed to heating at the temperature $T=+60^{\circ} \mathrm{C}$ for $12 \mathrm{~h}$.

The use of polishing compound No. 2 is also possible with the processing of smallsized organic crystals designed to joint work with SiPM. This requires high accuracy of the adherence to required dimensions. In this case we've investigated the detector based on a single crystal of activated $p$-terphenyl of $6 \times 6 \times 6 \mathrm{~mm}^{3}$ dimensions coupled by SiPM comprising 57,600 pixels with common sensitive area of $6 \times 6 \mathrm{~mm}^{2}$. Each pixel of referred above "Hamamatsu Photonics" SiPM type has a size of $25 \times 25 \mu \mathrm{m}$. To preserve the required dimensions and shape, all the surfaces of the scintillator were polished with Composition No. 2, which did not allow excessive dissolution of the crystal sections.

Measurements of the scintillation characteristics were being carried out at an overvoltage value for the SiPM of $U_{o v}=3.5 \mathrm{~V}$, and at its stabilized temperature $T=15^{\circ} \mathrm{C}$. As the source, we used the radionuclide of ${ }^{207} \mathrm{Bi}$ (electrons with energies $E_{e}=482$, 554, 976 and $1048 \mathrm{keV}$, and gamma quanta with energies $E_{\gamma}=570,1064$, and $1770 \mathrm{keV}$ ). During the experiment, the source was located directly above the scintillator being tested. The signal from the photodetector was fed to a shaping amplifier, which forms pseudo-Gaussian pulses at its output. The 
Table 2. Scintillation characteristics of single-crystalline organic scintillators when their input surfaces are treated with different polishing compounds before and after exposure to a high temperature

\begin{tabular}{|c|c|c|c|c|c|c|}
\hline \multirow[t]{3}{*}{ No. } & \multirow{3}{*}{$\begin{array}{l}\text { Scintillator material, } \\
\text { dimensions, mm }\end{array}$} & \multirow{3}{*}{$\begin{array}{l}\text { Polishing } \\
\text { compound }\end{array}$} & \multicolumn{4}{|c|}{ Scintillation characteristics * } \\
\hline & & & \multicolumn{2}{|c|}{ Before tests } & \multicolumn{2}{|c|}{$\begin{array}{l}\text { After exposure to a } \\
\text { temperature of }+60^{\circ} \mathrm{C} \text { for } \\
12 \mathrm{~h}\end{array}$} \\
\hline & & & $\begin{array}{l}\text { Channel } \\
\text { number }\end{array}$ & $R, \%$ & $\begin{array}{l}\text { Channel } \\
\text { number }\end{array}$ & $R, \%$ \\
\hline 1 & Stilbene single crystal $\varnothing 30 \times 2$ & 1 & 1250 & 10,5 & 1246 & 10.6 \\
\hline 2 & " & 2 & 1390 & 9.4 & 1395 & 9.4 \\
\hline 3 & Stilbene single crystal $\varnothing 15 \times 2$ & 1 & 1040 & 9.8 & 1035 & 9.9 \\
\hline 4 & " & 2 & 1170 & 8.6 & 1160 & 8.7 \\
\hline 5 & $\begin{array}{l}\text { Activated } p \text {-terphenyl single } \\
\text { crystal } \varnothing 30 \times 5\end{array}$ & 1 & 1260 & 8.2 & 1255 & 8.3 \\
\hline 6 & $n+$ & 2 & 1420 & 7.6 & 1435 & 7.5 \\
\hline
\end{tabular}

$*$ - scintillation characteristics were obtained by excitation with ${ }^{137} \mathrm{Cs}$ conversion electrons $\left(E_{e}=624 \mathrm{keV}\right)$.

shaper consists of a single passive differentiation circuit, of two active and one passive integration circuits. The common gain measured via detector input by the circuit comprising the charge-sensitive preamplifier and a shaper was equal to $G=7.4$. The shaping time was equal to $\tau=0.15 \mu \mathrm{s}$.

In order to convert the generated pulses into a digital code, a high-speed spectrometric amplitude-to-digital converter (ADC) of B4K CACP-USB type was used. We have supposed the exposure time $t=30 \mathrm{~min}$ will be enough to obtain correct energy spectra. The scale division of the ADC was $K=$ $1.8 \mathrm{mV} /$ channel.

\section{Results and discussion}

Optical and scintillation characteristics of organic scintillators single-crystal samples when their input surfaces have been treated with different polishing compositions are presented in Table 1 . Above mentioned characteristics were obtained upon excitation with $\alpha$-particles. The analysis of the data presented in Table 1 allows us to conclude that usage of the polishing compound No. 2 provides an increase in the transparency of scintillators as compared to the treatment options with composition No. 1. Accordingly, the scintillation characteristics are also improved.

A soft chemical interaction with the surface of the organic crystal is ensured when we use the polishing composition No. 2. As a result, microroughness and traces of the previous treatment (abrasive grinding or micro turning with a diamond cutter) are removed. The use of ethanol in the buffing composition makes it possible to reduce the elastic stresses during polishing. Incorporation of ethylene glycol, which is capable of adsorbing on the surface of organic crystals, slows down their dissolution process, reduces the deviation of their linear dimensions and shapes from the given geometry.

The incorporation of the fine-grained silicon dioxide and the ethylene glycol onto polishing composition creates a damper layer, which has thixotropic properties. The latter contributes to the uniform distribution of alumina particles therein. The presence of a damper layer provides gentle contact of the alumina particles with the surface being treated. This leads to a reduction in the disrupted layer, and an improvement in the quality of the polished surface.

The improvement of translucence with an increase of the input surface' quality can be explained by reducing the average angle of inclination of micro-surfaces with respect to the orthogonally falling outward light flux. This leads to a decrease of the light reflection coefficient for this flow at the entrance surface as compared to the surface with lower quality. At the same time, an increase in the light yield (both for alpha-particles and for conversion electrons) occurs for scintillators with the input surface of higher quality. This is also can be explained by the decrease in the deviation of microsurfaces' inclinations on the input surface of the scintillator. In this case, the microsurfaces are situated mainly in the plane of the entrance window. They are oriented at large angles to the scintillation rays preferably, providing high light reflection coeffi- 
Table 3. Scintillation characteristics for detector based on an activated $p$-terphenyl single crystal $6 \times 6 \times 6 \mathrm{~mm}^{3}$ obtained using SiPM as a photodetector when excitation by ${ }^{207} \mathrm{Bi}$ conversion electrons

\begin{tabular}{|c|c|c||}
\hline \multirow{2}{*}{$\begin{array}{c}\text { The energy } \\
\text { of elec- } \\
\text { trons, keV }\end{array}$} & \multicolumn{2}{|c|}{\begin{tabular}{c} 
Scintillation characteristics \\
\cline { 2 - 3 }
\end{tabular}} \\
\hline 1048 & 2571 & 5.7 \\
976 & 2390 & 7.9 \\
554 & 1343 & 11.9 \\
\hline
\end{tabular}

cients inside the crystal volume, and further to the output window. An improvement of the energy resolution can be related either with the enhancement in the statistics of photoelectrons (or electron-hole pairs for SiPM) with an increase of light flux, which does not fall onto photodetector, or with a decrease in the radial irregularity of light gathering for a planar detector when surface quality improves.

The light yield of scintillators based on stilbene single crystals and activated $p$-terphenyl single crystals is 12-15\% higher, and the energy resolution is $10-12 \%$ better after polishing the input surface with composition No. 2 than after polishing by composition No. 1.

Scintillation characteristics of organic scintillators single-crystal samples when their input surfaces are treated with different polishing compositions are presented in Table 2. Results were obtained upon excitation by conversion electrons $\left(E_{e}=624 \mathrm{keV}\right.$ of ${ }^{137} \mathrm{Cs}$ radionuclide) before and after tests on heat resistance. It can be seen from the Table 2 the use of polishing compound No. 2 also improves the light yield and energy resolution on 10-11\% for detectors based on stilbene and activated $p$-terphenyl single crystals, by registering conversion electrons with an energy of $E_{e}=624 \mathrm{keV}$ as compared with usage of the polishing composition No. 1. It is seen also all the detectors with stood the test at the temperature of $T=+60^{\circ} \mathrm{C}$ for $12 \mathrm{~h}$, as the scintillation characteristics of the detectors remained practically unchanged.

The results of measurements of scintillation characteristics for detector based on a $p$-terphenyl single crystal of small size $\left(6 \times 6 \times 6 \mathrm{~mm}^{3}\right)$ by using the SiPM are shown in Table 3, and in Figure. The results obtained for this case show a sufficiently high spectrometric quality of this sample of the detector when processing surfaces of the

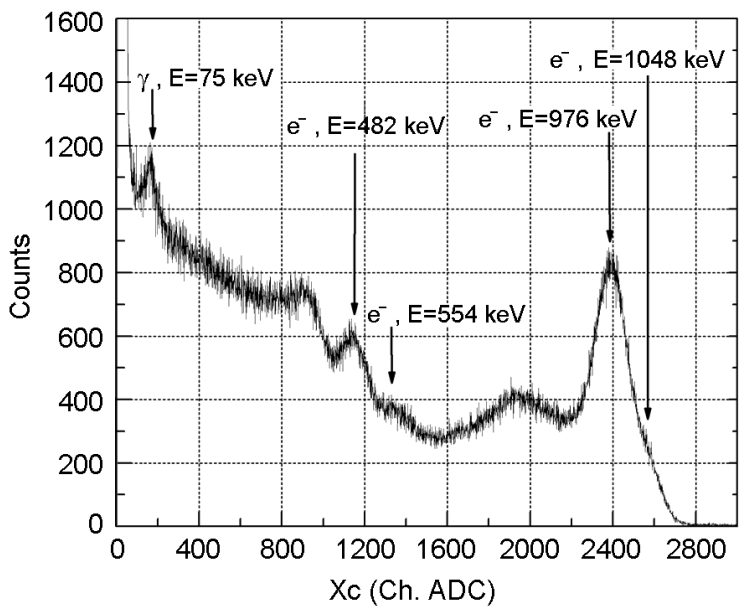

Fig. Energy spectrum for ${ }^{207} \mathrm{Bi}$ conversion electrons measured by the "SiPM- $p$-terphenyl" assembly.

scintillator with a selected polishing compound.

\section{Conclusions}

In the course of research, an opportunity has been found and realized for improving the quality of the surface for organic crystalline scintillators, to improve the accuracy of their shapes, to enhance scintillation characteristics of detectors (when detecting $\alpha$-particles and conversion electrons), as well to ensure their thermal resistance.

Improving scintillation characteristics became possible as a result of choosing the composition for chemical-mechanical polishing of the organic scintillators' surfaces. The composition possesses thixotropic properties, provides a soft chemical interaction with the scintillator surface, slows down the dissolution of organic crystal segments, and provides a soft contact of abrasive particles with the surface. All noted above reduces the amount of the disrupted layer and improves the quality of the polished surface.

Correct proportioning of the mixture for polishing compound also made it possible to obtain a small-sized high-spectrometric detector based on an activated $p$-terphenyl single crystal assembled with the SiPM. The design and technological features of manufacturing the detector meets the requirements for the development of scintillation techniques, since they allow increasing the accuracy of the scintillator shape, providing a high light yield and energy resolution. Obtained experimentally in this work energy resolution, when detecting $\beta$-particles with energies of $E_{e}=1048,976$ and 
$554 \mathrm{keV}$ by usage the radionuclide ${ }^{207} \mathrm{Bi}$, was equal to $R=5.7,7.9$ and $11.9 \%$, respectively.

\section{References}

1. N.Z.Galunov, V.P.Seminozhenko, Radioluminescence of Organic Condensed Media. Theory and Application, Naukova Dumka, Kiev (2015) [in Russian].

2. L.A.Lisitsyna, I.A.Tupitsyna, L.N.Trefilova, in: Proc. IOP Conf. Series: Materials Science and Engineering, 81, 012024 (2015).

3. O.V.Dudnik, M.Prieto, E.V.Kurbatov et al., Kosm. Nauka Tekhnol., 18, 22 (2012).

4. O.V.Dudnik, L.A.Andryushenko, V.A.Tarasov, E.V.Kurbatov, Instrum.Exp.Tech., 58, 206 (2015).

5. Yu.L.Zabulonov, V.M.Burtnyak, L.A.Odukalets, Nauka Innov., 13, 46 (2017).

6. L.A.Andryushchenko, S.V.Budakovskii, N.Z.Galunov et al., Instrum.Exp.Tech., 42, 759 (1999).

7. A.A.Ananenko, L.A.Andryushchenko, Yu.T.Vydai et al., Instrum.Exp.Tech., 51, 795 (2008).

8. L.A.Andryushchenko, S.V.Budakovskii, N.Z.Galunov et al., Instrum.Exp.Tech., 46, 591 (2003).
9. N.Z.Galunov, O.A.Tarasenko, V.A.Tarasov, $J$. Appl.Spectr., 80, 550 (2013).

10. A.M.Kudin, Yu.A.Borodenko, B.V.Grinyov et al., Instrum. Exp. Tech., 53, 39 (2010).

11. Patent Russia, 2142147, (1999).

12. O.V.Dudnik, E.V.Kurbatov, V.A.Tarasov et al., Nucl.Inst. Meth. Phys. Res. A, 664, 148 (2012).

13. L.A.Andryushenko, B.V.Grinev, V.A.Tarasov, Instrum. Exp. Tech., 54, 603 (2011).

14. Yu.V.Milman, N.Z.Galunov, S.I.Chugunova et al., Nanosistemy, Nanomaterialy, Nanotehnologii, 14, 461 (2016).

15. V.V.Rogov, A.G.Vetrov, A.A.Boyarintsev, $J$. Superhard Mater., 6, 85 (2003).

16. Ya.A.Kosenok, V.E.Gayshun, O.I.Tyulenkova et al., Nanosistemy, Nanomaterialy, Nanotehnologii, 12, 269 (2014).

17. A.S.Artyomov, Fizika Tverdogo Tela, 46, 670 (2004).

18. L.A.Andryushenko, L.I.Voloshina, I.D.Vlasova et al., Instrum.Exp. Tech., 55, 179 (2012).

19. L.A.Andryushenko, B.V.Grinev, Instrum. Exp. Tech., 41, 447 (1998).

20. P.Rodzyal, Hermetic Sealing of REA Elements, Radio i Svyaz', Moscow (1981) [in Russian].

21. T.A.Gorbacheva, V.A.Tarasov, Yu.T.Vidayi et al., Functional Materials, 15, 97 (2008). 